\title{
INTERACTION OF THREE-DRUG COMBINATION OF LACOSAMIDE, CARBAMAZEPINE AND PHENOBARBITAL IN THE MOUSE MAXIMAL ELECTROSHOCK-INDUCED SEIZURE MODEL - AN ISOBOLOGRAPHIC ANALYSIS
}

\author{
INTERAKCJA TRÓJLEKOWEJ KOMBINACJI LAKOZAMIDU, KARBAMAZEPINY \\ I FENOBARBITALU W TEŚCIE MAKSYMALNEGO WSTRZĄSU ELEKTRYCZNEGO \\ U MYSZY - ANALIZA IZOBOLOGRAFICZNA
}

\author{
Maria W. Kondrat-Wróbel ${ }^{1(\mathrm{~A}, \mathrm{~B}, \mathrm{E}, \mathrm{F})}$, Jarogniew J. Luszczki ${ }^{1(\mathrm{~A}, \mathrm{~B}, \mathrm{C}, \mathrm{D}, \mathrm{E}, \mathrm{F}, \mathrm{G})}$
}

${ }^{1}$ Department of Pathophysiology, Medical University of Lublin, Poland

Authors' contribution Wkład autorów: A. Study design/planning zaplanowanie badań B. Data collection/entry zebranie danych C. Data analysis/statistics dane - analiza i statystyki D. Data interpretation interpretacja danych E. Preparation of manuscript przygotowanie artykułu F. Literature analysis/search wyszukiwanie $i$ analiza literatury G. Funds collection zebranie funduszy

\begin{abstract}
Summary
Background. Epilepsy is one of the serious neurological diseases characterized by seizures that affect about $1 \%$ of people worldwide ( 65 million), and therefore, epilepsy can be considered as a disease of civilization. Although seizures are controllable with antiepileptic drugs (AEDs) in about $70 \%$ of cases, it remains still about $30 \%$ of epilepsy patients inadequately medicated with these AEDs, who need a full control of their seizure attacks. One of the treatment options in these patients is application of two or three AEDs in combination. The aim of this study was to characterize the anticonvulsant effects of a combination of three AEDs (i.e., carbamazepine [CBZ], lacosamide [LCM] and phenobarbital [PB]) at the fixed-ratio of 1:1:1 in the mouse maximal electroshock (MES)-induced seizure model.

Materials and methods. Tonic hind limb extension (seizure activity) was evoked in adult male albino Swiss mice by a current (sine-wave, $25 \mathrm{~mA}, 500 \mathrm{~V}, 50 \mathrm{~Hz}, 0.2 \mathrm{~s}$ stimulus duration) delivered via auricular electrodes. Type I isobolographic analysis was used to analyze the three-drug combination. Results. Type I isobolographic analysis revealed that the combination of CBZ, LCM and PB (at the fixed-ratio of $1: 1: 1)$ exerted additive interaction with a slight tendency towards antagonism in the mouse MES-induced seizure model.

Conclusions. A special caution is advised to patients taking LCM in combination with CBZ and $\mathrm{PB}$ because this three-drug combination offered additive interaction with a slight tendency towards antagonism in the mouse MES model.
\end{abstract}

Keywords: antiepileptic drugs, isobolographic analysis, maximal electroshock, three-drug combination

\section{Streszczenie}

Wprowadzenie. Padaczka jest jedną z poważnych chorób neurologicznych charakteryzującą się występowaniem drgawek, które dotykają około $1 \%$ ludzi na świecie (65 milionów) i dlatego też padaczka może być uważana za chorobę cywilizacyjną. Chociaż drgawki padaczkowe kontrolowane są lekami przeciwpadaczkowymi w około $70 \%$ przypadków, wciąż pozostaje około $30 \%$ pacjentów z padaczką niewłaściwie leczonych tymi lekami, którzy wymagają pełnej kontroli napadów. Jedną z opcji leczniczych u tych pacjentów jest zastosowanie dwóch lub trzech leków przeciwpadaczkowych w kombinacji. Celem badania była ocena działania przeciwdrgawkowego kombinacji trzech leków przeciwpadaczkowych (tj.: karbamazepiny [CBZ], lakozamidu [LCM] i fenobarbitalu [PB]) w stałej proporcji dawek 1:1:1 w teście maksymalnego wstrząsu elektrycznego u myszy.

Materiały i metody. Toniczny wyprost kończyn tylnych (aktywność drgawkową) wywoływano u dorosłych myszy szczepu albino Swiss prądem (25 mA, $500 \mathrm{~V}, 50 \mathrm{~Hz}, 0,2 \mathrm{~s}$ czas stymulacji) dostarczanym przez elektrody uszne. Zastosowano typ I analizy izobolograficznej do oceny trójlekowej kombinacji.

Wyniki. Typ I analizy izobolograficznej wykazał, że kombinacja CBZ, LCM i PB (w stałej proporcji dawek 1:1:1) wykazuje interakcje addytywną z niewielką tendencją do antagonizmu w teście maksymalnego wstrząsu elektrycznego u myszy.

Wnioski. Zaleca się szczególną ostrożność pacjentom przyjmującym LCM do kombinacji CBZ i PB ponieważ ta trójlekowa kombinacja oferuje addycję z niewielką tendencją do antagonizmu w teście maksymalnego wstrząsu elektrycznego u myszy.

Słowa kluczowe: leki przeciwpadaczkowe, analiza izobolograficzna, maksymalny wstrząs elektryczny, trójlekowe kombinacje
Tables: 0

Figures: 0

References: 40

Submitted: 07.01.2016

Accepted: 19.02 .2016
Kondrat-Wrobel MW, Luszczki JJ. Interaction of three-drug combination of lacosamide, carbamazepine and phenobarbital in the mouse maximal electroshock-induced seizure model - an isobolographic analysis. Health Problems of Civilization 2016; 10(1): 55-61. DOI: 10.5114/hpc.2016.58209 


\section{Background}

In spite of advanced knowledge on pathophysiological processes underlying epileptogenesis and a wide range of antiepileptic drugs (AEDs), currently available for the treatment of patients with epilepsy, there is still about $30 \%$ of epilepsy patients inadequately medicated with these AEDs in monotherapy [1-3]. For these patients, some new therapeutic options are required to stop their seizures so as not to decrease their quality of lives [2-4]. Of these options, combinations of various AEDs in duo- and triple therapy and/or application of some novel AEDs in monotherapy seem to be the most adequate [5,6]. At present, several two-drug and three-drug combinations are recommended for patients, who are resistant to monotherapeutic use of the first-line AEDs [2,3]. From a clinical point of view, there exists a general rule for combining AEDs to provide the most advantageous combinations. This rule is based on co-administration of AEDs with diverse molecular mechanisms of anticonvulsant action in order to complementary enhance their antiseizure effects in the mixture [6,7]. Simultaneously, the ideal AED combination should reduce side effects of the AEDs in mixture $[7,8]$.

Because the assessment and characterization of types of interactions among AEDs in clinical trials is very difficult and performed empirically, pre-clinical studies on animals may help to provide evident information on the exact nature of interaction occurring among drugs. In such cases, pre-clinical in vivo experiments can confirm whether or not the theoretically selected AED combinations are favorable [8].

Lacosamide (LCM) is a novel third-generation AED that has recently been licensed as adjunctive therapy in the treatment of partial-onset seizures with or without secondary generalization in adult patients with epilepsy [9-11]. Similarly, carbamazepine (CBZ) and phenobarbital (PB) - two AEDs are widely used in patients with tonic-clonic seizures and partial convulsions [12]. From a clinical viewpoint, the combined application of LCM with CBZ or PB should result in a favorable combination because it should offer suppression of tonic-clonic seizures in patients with epilepsy refractory to the separate use of these AEDs in monotherapy [13]. Additionally, the selection of this three-drug combination (LCM, CBZ and PB) in our study fulfils theoretical criteria of an ideal AED combination providing maximal therapeutic effects along with minimal or no toxic effects [7]. However, this hypothesis needs experimental verification and confirmation in the mouse MES model. Of note, the maximal electroshock-induced seizures (MES) are thought to be an experimental model of tonic-clonic seizures and, to a certain extent, of partial onset seizures with or without secondary generalization in humans [14]. This is the reason to conduct experiments using LCM, CBZ and PB in this seizure model.

The aim of this study was to experimentally assess and characterize the type of interactions among three AEDs (LCM, CBZ and PB) in the mouse MES model. The characteristics of interaction among LCM, CBZ and PB was evaluated with type I isobolographic analysis, which is considered to be the method of choice for examining interaction in pre-clinical studies [15].

\section{Materials and methods}

All experiments were carried out on adult male albino Swiss mice (weighing 22-26 g) purchased from a licensed breeder (Dr. J. Kolacz, Warszawa, Poland). The experimental protocols and procedures described hereupon were approved by the Second Local Ethics Committee at the University of Life Sciences in Lublin (License no.: 45/2014).

The following AEDs were used in this study: CBZ (Polfa, Starogard Gdanski, Poland), LCM (Vimpat ${ }^{\circledR}$, UCB Pharma, Brussels, Belgium), and PB (Polfa, Kraków, Poland). All drugs were suspended in a 1\% solution of Tween 80 (SigmaAldrich, Poznań, Poland) in distilled water and were administered i.p. in a volume of $5 \mathrm{ml} / \mathrm{kg}$ body weight as follows: $\mathrm{LCM}$ and CBZ at $30 \mathrm{~min}, \mathrm{~PB}$ at $60 \mathrm{~min}$, prior to maximal electroconvulsions.

Maximal electroconvulsions (seizure activity) were produced by a current $(25 \mathrm{~mA}, 500 \mathrm{~V}, 50 \mathrm{~Hz}, 0.2 \mathrm{~s}$ stimulus duration) delivered via standard auricular electrodes by a Hugo Sachs generator (Rodent Shocker, Type 221, Freiburg, Germany). The criterion for the occurrence of seizure activity was the tonic hind limb extension. The animals were administered with different drug doses so as to obtain a variable percentage of protection against MES-induced seizures, allowing for the construction of a dose-response effect line (DREL) for the studied AEDs administered alone, according to Litchfield and Wilcoxon [16]. The protective activities of CBZ, LCM and PB administered separately and their combinations were evaluated and expressed as their median effective doses $\left(\mathrm{ED}_{50} \mathrm{in} \mathrm{mg} / \mathrm{kg}\right)$, protecting $50 \%$ of mice against MES-induced seizures. The anticonvulsant activity of the mixture of LCM, CBZ and PB at the fixed-ratio of 1:1:1 was evaluated and expressed as the experimental median effective dose $\left(E_{50 \text { exp }}\right.$ value) against MES-induced seizures.

To assess the nature of interactions among three drugs in combination in preclinical studies on animals, an isobolographic analysis of interaction was applied according to the method described earlier [15, 17]. The percentage of animals protected against MES-induced seizures per dose of an AED administered singly and the 
dose-response effect line (DREL) for each investigated AED in the mouse MES model were fitted using log-probit linear regression analysis according to Litchfield and Wilcoxon [16]. The median effective doses $\left(\mathrm{ED}_{50}\right.$ values) of AEDs administered alone were calculated from the respective linear equations. The test for parallelism of DRELs for LCM, PB and CBZ based on the log-probit analysis was used. Subsequently, the median additive doses of the threedrug mixture of $\mathrm{LCM}, \mathrm{PB}$ and CBZ $\left(\mathrm{ED}_{50 \text { add }}\right.$ - i.e., a dose of the three-drug mixture, which theoretically should protect $50 \%$ of the animals tested against MES-induced seizures) for the fixed-ratio combination of 1:1:1 was calculated from the equation of additivity, as follows: $x / \mathrm{ED}_{50 \_\mathrm{LCM}}+y / \mathrm{ED}_{50 \_\mathrm{PB}}+z / \mathrm{ED}_{50 \mathrm{CBZ}}=1$; where $x$ - is the dose of LCM, $y-$ is the dose of $\mathrm{PB}$, and $z$ - is the dose of CBZ, co-administered as a mixture that exerts the desired effect (50\% effect for $\mathrm{ED}_{50}$, respectively. The calculation of the $\mathrm{ED}_{50 \text { add }}$ value for the three-drug mixture at the fixed-ratio combination of 1:1:1 is always associated with determination of fractions of three drugs in mixture, as follows: $\mathrm{ED}_{50 \text { add }}=\left(\mathrm{f}_{\mathrm{LCM}}\right.$ $\left.\times \mathrm{ED}_{50 \_\mathrm{LCM}}\right)+\left(\mathrm{f}_{\mathrm{PB}} \times \mathrm{ED}_{50 \mathrm{~PB}}\right)+\left(\mathrm{f}_{-\mathrm{CBZ}} \times \mathrm{ED}_{50-\mathrm{CBZ}}\right)$; where: $\mathrm{f}_{\mathrm{LCCM}}, \mathrm{f}_{\mathrm{PBB}}$ and $\mathrm{f}_{-\mathrm{CBZ}}-$ are the fractions of LCM, PB and CBZ in a total amount of the mixture, respectively. Thus, for the three-drug mixture the above expression is true when: $\mathrm{f}_{\mathrm{LCM}}+\mathrm{f}_{\mathrm{PB}}+\mathrm{f}_{\mathrm{CBZ}}=1$. To simplify the notation and nomenclature of interactions in isobolography, the drug doses were administered at the fixed-ratio combination (e.g. 1:1:1). The fixed-ratio combination of 1:1:1 refers to ratios that were based on the $\mathrm{ED}_{50}$ values of the constituent drugs. In this study, the mixture at the fixed-ratio of 1:1:1 comprised $1 / 3$ of the $\mathrm{ED}_{50}$ of $\mathrm{LCM}, 1 / 3$ of the $\mathrm{ED}_{50}$ of $\mathrm{PB}$ and ${ }^{1} /{ }_{3}$ of the $\mathrm{ED}_{50}$ of $\mathrm{CBZ}$. Thus, the isobolographic notation of the fixed-ratio combination comprises numerators of fractions of $\mathrm{ED}_{50}$ values for AEDs used in the mixture (1:1:1). Afterwards, proportions of the AEDs in the mixture were calculated and the respective mixtures of LCM, PB and CBZ were administered to animals. The anticonvulsant effects offered by the studied AEDs in combination at the fixed-ratio of 1:1:1 in the mouse MES model were evaluated and expressed as the experimentally-derived $\mathrm{ED}_{50 \text { exp }}$ value, corresponding to a dose of three-drug mixture, sufficient for the $50 \%$ protective effect against MESinduced seizures in mice. Finally, to determine the separate doses of LCM, PB and CBZ in the mixture, the $\mathrm{ED}_{50 \text { exp }}$ and $\mathrm{ED}_{50 \text { add }}$ values were multiplied by the respective proportions of AEDs.

The experimentally-derived $\mathrm{ED}_{50 \text { exp }}$ value for the mixture of $\mathrm{LCM}, \mathrm{PB}$ and $\mathrm{CBZ}$ at the fixed-ratio of 1:1:1 was statistically compared with its respective theoretical additive $\mathrm{ED}_{50 \text { add }}$ value by using the unpaired Student's $t$-test. All statistical tests were performed using GraphPad Prism version 5.0 for Windows (GraphPad Software, San Diego, CA, USA).

\section{Results}

LCM, PB and CBZ administered alone produced a clear-cut anticonvulsant effect against MES-induced seizures. The equations of DRELs for LCM ( $y=7.6636 \mathrm{x}-1.6044$; Figure 1), PB ( $y=12.428 \mathrm{x}-13.572$; Figure 1$)$, and CBZ ( $\mathrm{y}$ $=14.671 \mathrm{x}-11.93$; Figure 1), allowed the determination of the $\mathrm{ED}_{50}$ values for LCM, PB and CBZ, which were 7.27 $\pm 0.77 \mathrm{mg} / \mathrm{kg}, 31.21 \pm 2.04 \mathrm{mg} / \mathrm{kg}$ and $14.25 \pm 0.79 \mathrm{mg} / \mathrm{kg}$, respectively (Table 1 ).

Table 1. Anticonvulsant effects of carbamazepine (CBZ), lacosamide (LCM), and phenobarbital (PB) administered singly against maximal electroshock (MES)-induced seizures in mice

\begin{tabular}{|l|l|l|l|l|l|l|}
\hline Drug & ED $_{50}$ & $n$ & Drug combination & S. R. & f ratio S.R. & Test for parallelism \\
\hline CBZ & $14.25 \pm 0.79$ & 16 & LCM vs. CBZ & 1.154 & 1.126 & non-parallel \\
\hline LCM & $7.27 \pm 0.77$ & 16 & LCM vs. PB & 1.122 & 1.134 & parallel \\
\hline PB & $31.21 \pm 2.04$ & 16 & CBZ vs. PB & 1.029 & 1.107 & parallel \\
\hline
\end{tabular}

Results are presented as median effective doses $\left(\mathrm{ED}_{50}\right.$ values in $\mathrm{mg} / \mathrm{kg} \pm$ S.E.M.) of CBZ, LCM and PB administered singly against MES-induced seizures in mice. The drugs were administered systemically (i.p.), as follows: CBZ and LCM - 30 min, PB - 60 min before the MES-induced seizures. $n$ - total number of animals used at doses whose expected anticonvulsant effects ranged between $4^{\text {th }}$ and $6^{\text {th }}$ probit $(16 \%$ and $84 \%)$; S.R. - slope function ratio for the respective two-drug combinations (i.e., $\mathrm{S}_{\mathrm{LCM}} /$ $\mathrm{S}_{\mathrm{PB}}, \mathrm{S}_{\mathrm{LCM}} / \mathrm{S}_{\mathrm{CBZ}}$, and $\mathrm{S}_{\mathrm{PB}} / \mathrm{S}_{\mathrm{CBZ}}$ ); f ratio S.R. - factor for slope function ratio for the respective two-drug combinations. \#Test for parallelism: if the S.R. value determined for two dose-response effect lines (DRELs) is lower than the $f$ ratio S.R. value (S.R. $<\mathrm{f}$ ratio S.R.), the examined two DRELs are parallel to one another [16].

Source: own elaboration.

The test for parallelism of DRELs between LCM and PB, CBZ and PB revealed that the drugs had their DRELs parallel to each other (Table 1). In contrast, DRELs between LCM and CBZ are non-parallel to one another (Table 1). The three-drug combination of LCM, PB and CBZ at the fixed-ratio of 1:1:1 exerted the anticonvulsant activity in the MES test and the experimentally derived $\mathrm{ED}_{50 \exp }$ value for the mixture of three AEDs ( $\mathrm{y}=5.7745 \mathrm{x}-2.6105$; Figure 1) was $20.79 \pm 2.39 \mathrm{mg} / \mathrm{kg}$ (Table 2; Figure 2). 
Table 2. Type I isobolographic analysis of interaction among carbamazepine (CBZ), lacosamide (LCM) and phenobarbital (PB) at the fixed-ratio of 1:1:1 in the mouse maximal electroshock (MES)-induced seizure model

\begin{tabular}{|l|l|l|l|l|l|l|l|l|l|}
\hline $\mathrm{ED}_{50 \exp }$ & $n_{\exp }$ & $\mathrm{LCM}_{\exp }$ & $\mathrm{PB}_{\exp }$ & $\mathrm{CBZ}_{\exp }$ & $\mathrm{ED}_{50 \text { add }}$ & $n_{\text {add }}$ & $\mathrm{LCM}_{\text {add }}$ & $\mathrm{PB}_{\text {add }}$ & $\mathrm{CBZ}_{\text {add }}$ \\
\hline $20.79 \pm 2.39$ & 24 & 2.87 & 12.31 & 5.62 & $17.58 \pm 0.70$ & 50 & 2.42 & 10.40 & 4.75 \\
\hline
\end{tabular}

Data are presented as median effective doses $\left(\mathrm{ED}_{50}\right.$ values in $\mathrm{mg} / \mathrm{kg} \pm$ S.E.M.) protecting $50 \%$ of animals tested against MES-induced seizures. The $\mathrm{ED}_{50}$ values were either experimentally determined from the mixture of three drugs $\left(\mathrm{ED}_{50 \mathrm{exp}}\right)$ or theoretically calculated as additive for the three-drug mixture $\left(\mathrm{ED}_{50}\right)$. The actual doses of $\mathrm{LCM}, \mathrm{PB}$ and $\mathrm{CBZ}$ that comprised the mixtures at the fixed-ratio combination of 1:1:1 for both $\mathrm{ED}_{50 \mathrm{exp}}$ and $\mathrm{ED}_{50 \text { add }}$ values are presented in separate columns. Statistical evaluation of data was performed by using unpaired Student's $t$-test. $n$-total number of animals used at those doses whose expected anticonvulsant effects were ranged between $4^{\text {th }}$ and $6^{\text {th }}$ probit, denoted for the experimental mixture of drugs $(n$ exp $)$ and theoretically calculated $\left(n_{\text {add }}=n_{-\mathrm{LCM}}+n_{-\mathrm{PB}}+n_{-\mathrm{CBZ}}-6\right)$.

Source: own elaboration.

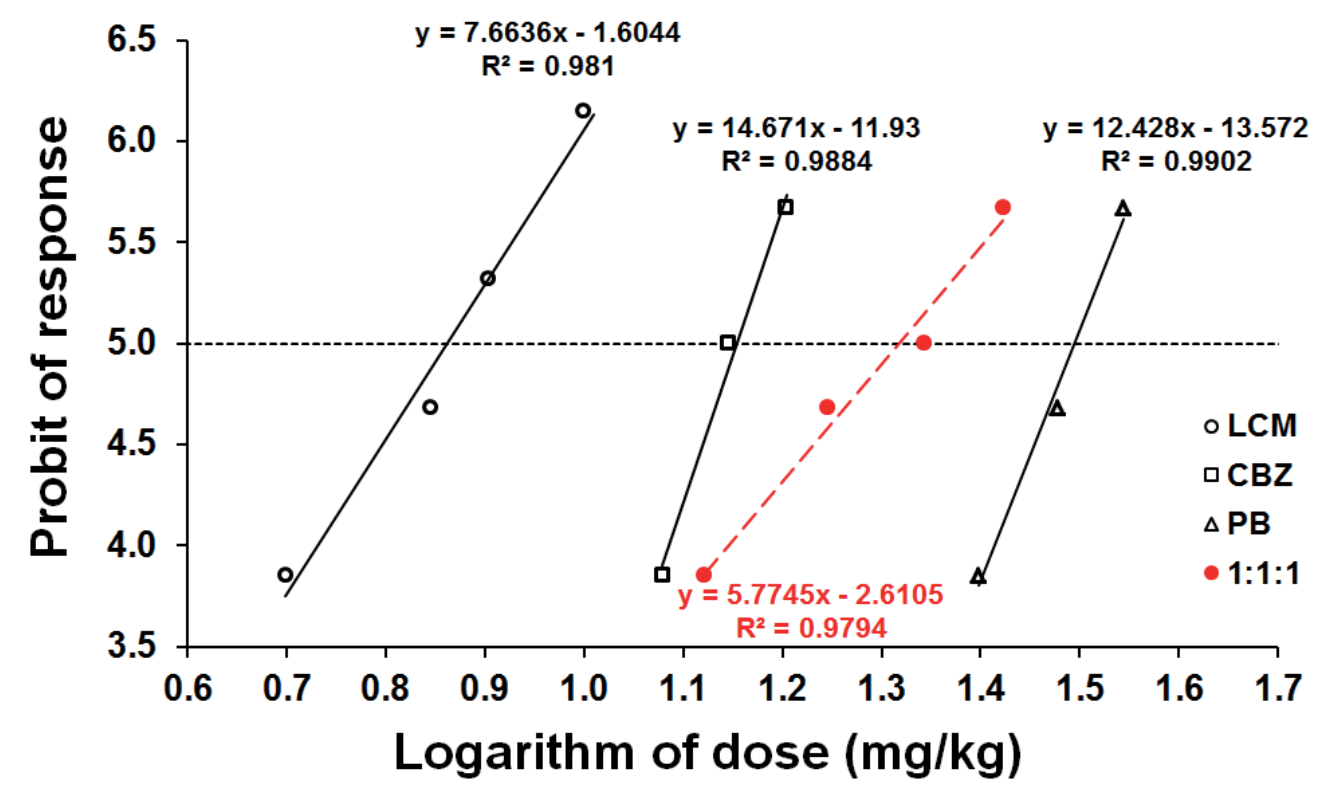

Figure 1. Log-probit dose-response effect lines (DRELs) of carbamazepine (CBZ), lacosamide (LCM) and phenobarbital (PB) administered alone and in combination at the fixed-ratio of 1:1:1 against maximal electroshock (MES)-induced seizures in mice

Doses of CBZ, LCM and PB administered alone and in combination at the fixed-ratio of 1:1:1 were transformed to logarithms, whereas the protective (anticonvulsant) effects offered by the AEDs against MES-induced seizures were transformed to probits according to Litchfield and Wilcoxon [16]. Linear regression equations of dose-response effects for CBZ, LCM and PB administered alone and in combination are presented on the graph; where $\mathrm{y}$ - is the probit of response; $\mathrm{x}$ - is the logarithm (to the base 10) of an AED dose or a dose of the mixture of the studied AEDs; and $\mathrm{R}^{2}$ - coefficient of determination.

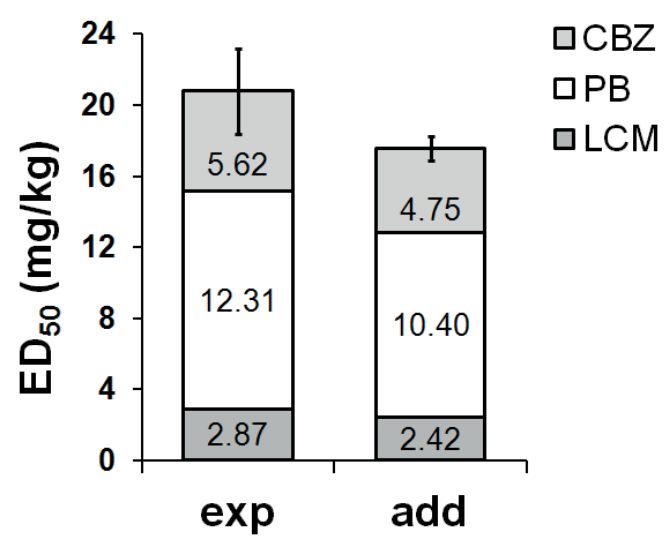

Figure 2. Doses of carbamazepine (CBZ), lacosamide (LCM) and phenobarbital (PB) in the three-drug mixture at the fixed-ratio combination of 1:1:1 against maximal electroshock (MES)-induced seizures in mice

Columns represent median effective doses $\left(\mathrm{ED}_{50} \mathrm{in} \mathrm{mg} / \mathrm{kg} \pm\right.$ S.E.M.) of the mixture of three drugs at the fixed-ratio of 1:1:1 that were experimentally determined in the MES-induced seizure test in mice (exp), and theoretically calculated as additive (add). Doses of CBZ, PB and LCM in combination at the fixed-ratio of 1:1:1 are presented as stacked bars. Statistical comparison of data was performed by using unpaired Student's $t$-test. 
The isobolographic analysis of interaction revealed that the three-drug mixture at the fixed-ratio of 1:1:1 exerted additive interaction with a slight tendency towards antagonism in the MES test in mice (Figure 3A-3C).
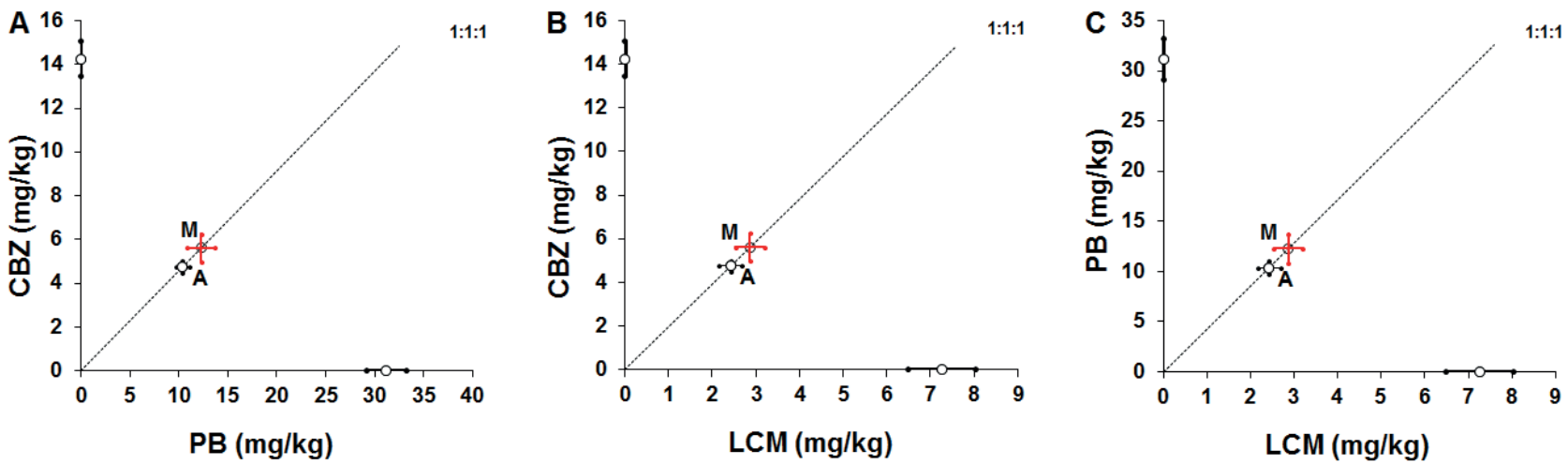

Figure 3A-3C. Isobolograms showing additive interactions among carbamazepine (CBZ), lacosamide (LCM) and phenobarbital (PB) against maximal electroshock (MES)-induced seizures in mice

The median effective doses ( $\mathrm{ED}_{50}$ values) for CBZ, LCM and PB are plotted graphically on X-axis and Y-axis (Figure 3A-3C). The solid lines on the $\mathrm{X}$ and $\mathrm{Y}$ axes represent the S.E.M. for the AEDs administered alone. The open circles (o) depict the experimentally-derived $\mathrm{ED}_{50 \mathrm{exp}} \mathrm{s}\left( \pm\right.$ S.E.M.) and theoretically calculated $\mathrm{ED}_{50 \text { add }} \mathrm{s}( \pm$ S.E.M.) for total doses expressed as the proportions of AEDs that produced a 50\% protection of animals against MES-induced seizures. The S.E.M. values are presented as horizontal and vertical error bars for the $\mathrm{ED}_{50 \text { exp }} \mathrm{s}$ and $\mathrm{ED}_{50 \text { add }} \mathrm{s}$. Points $\mathrm{M}$ and $\mathrm{A}$ on each graph reflect the $\mathrm{ED}_{50 \text { exp }}$ and $\mathrm{ED}_{50 \text { add }}$ values, respectively. The line starting from the point $(0,0)$ and crossing through the points $M$ and A corresponds to the fixedratio of 1:1:1 for the combination of CBZ, LCM and PB. The experimental $\mathrm{ED}_{50 \text { exp }}$ value of the three-drug mixture for the fixedratio of 1:1:1 is placed close to the theoretically calculated $\mathrm{ED}_{50 \text { add }}$ value, indicating the additive interaction.

(A) Interaction between CBZ and PB. The X- and Y-coordinates for all points presented on the isobologram are as follows: M $(12.31 ; 5.62)$ and $A(10.40 ; 4.75)$.

(B) Interaction between LCM and CBZ. The X-and Y-coordinates for all points presented on the isobologram are as follows: M $(2.87 ; 5.62)$ and $A(2.42 ; 4.75)$.

(C) Interaction between LCM and PB. The X- and Y-coordinates for all points presented on the isobologram are as follows: M $(2.87 ; 12.31)$ and $\mathrm{A}(2.42 ; 10.40)$.

The experimentally-derived $\mathrm{ED}_{50 \text { exp }}$ value for this fixed-ratio combination $(20.79 \pm 2.39 \mathrm{mg} / \mathrm{kg})$ did not differ significantly from the corresponding additively calculated $\mathrm{ED}_{50 \text { add }}$ value $(17.58 \pm 0.70 \mathrm{mg} / \mathrm{kg})$ (Table 2; Figure 2).

\section{Discussion}

Results presented herein indicate clearly that the three-drug combination of LCM, PB and CBZ at the fixed-ratio of 1:1:1 exerted additive interaction with a slight tendency towards antagonism in the mouse MES model. The observed anticonvulsant effect of the three-drug combination ( $\mathrm{LCM}+\mathrm{PB}+\mathrm{CBZ}$ ) can be compared with the results obtained for three two-drug combinations (i.e., $L C M+P B, L C M+C B Z$ and PB+CBZ) in the mouse MES model. The available experimental data indicated that the interaction between PB and CBZ in the mouse MES model was additive in nature [18]. At present, there is no information on the interaction between LCM and PB or CBZ in the mouse MES model. However, it was documented that the combination of LCM with CBZ produced supra-additive (synergistic) interaction in the mouse psychomotor seizure (6 Hz) model [19]. In light of the above-mentioned facts, the combination of three drugs (i.e., LCM, PB and CBZ) in the mouse MES model has no advantage over the combination of $\mathrm{CBZ}$ with $\mathrm{PB}$, as determined in this seizure model. On the other hand, evaluation of acute adverse effects for the AEDs in combination revealed that the tested three-drug mixture was devoid of any side effects with respect to motor coordination, long-term memory or skeletal muscular strength in mice (results not shown). Lack of any acute side effects in animals receiving the combination of LCM, PB and CBZ, in doses corresponding to the $\mathrm{ED}_{50 \text { exp }}$ value, indirectly indicated that the combination was safe enough to be used in further clinical trials.

It should be stressed that in this study we described, for the first time, a modified method of type I isobolographic analysis dedicated to assess the nature of pharmacodynamic interaction among three AEDs. As suggested in the Introduction, the combination of three AEDs (LCM, CBZ and PB) with various molecular mechanisms of anticonvulsant action should exerted beneficial interaction in the mouse MES model. It is important to note that the selection of AEDs to this three-drug combination (i.e., LCM, PB and CBZ) was based on theoretical presumptions 
related with diverse complementary molecular mechanisms of anticonvulsant action ascribed to these AEDs. More specifically, CBZ reduces the frequency of sustained repetitive firing of action potentials in neurons and blocks voltage-dependent sodium channels [20]. PB enhances $\gamma$-aminobutyric acid (GABA) $)_{A}$ receptor-mediated currents through the binding to an allosteric regulatory site on the $\mathrm{GABA}_{\mathrm{A}}$-benzodiazepine receptor-chloride ionophore complex $[21,22]$. Additionally, PB blocks excitatory responses induced by glutamate thereby the a-amino-3hydroxy-5-methyl-4-isoxazole-propionic acid (AMPA) receptors [23]. In the case of LCM, the drug through the selective enhancement of slow inactivation of voltage-gated sodium channels, stabilizes hyperexcitable neuronal membranes [24, 25]. The drug displays also affinity for the glycine strychnine-insensitive recognition site of the NMDA receptor complex, and allosterically blocks NMDA receptors with a specific action on receptors containing the NR2B subunit $[24,25]$.

Thus, considering the above-mentioned various molecular mechanisms of anticonvulsant action of the tested AEDs, the combination of LCM, CBZ and PB is expected to synergistically or additively suppress tonic-clonic seizures in experimental animals subjected to the MES test due to their complementary mechanisms of action.

Another fact needs special attention when explaining the results obtained in this isobolographic study. We used the combination of 3 drugs in doses that were 3-times lower than their corresponding $\mathrm{ED}_{50}$ values, as determined separately in the mouse MES model. This reduction of drug doses was dependent on an isobolographic equation of additivity, suggesting that every $n$-drug mixture must comprise $n$-times reduced $\mathrm{ED}_{50}$ values of the tested drugs alone; where $n$ - is the number of drugs used in combination. In any isobolographic case, the equation of additivity is equal to unity and we have results corresponding to monotherapy with one effective drug, in terms of suppression of MES-induced seizures in mice. It is worthy of noting that the reduction of drug doses is advantageous because of limitation of side effects of singly used drugs that would appear in experimental animals.

\section{Conclusions}

1. The three-drug combination of LCM, CBZ and PB exerted additive interaction with a slight tendency towards antagonism in the mouse MES model.

2. This three-drug combination should be avoided in clinical trials in patients with drug resistant epilepsy because it did not provide any additional advantages over the use of the combination of CBZ with PB.

3. LCM added to the combination of PB and CBZ did not change significantly the nature of additive interaction.

\section{Disclosures and acknowledgements}

The authors have no conflicts of interest to disclose. This study was supported by a grant (DS474/2012-2015) from the Medical University of Lublin (Poland).

\section{References:}

1. Kwan P, Brodie MJ. Combination therapy in epilepsy: When and what to use. Drugs. 2006; 66: 1817-1829.

2. Stephen LJ, Brodie MJ. Seizure freedom with more than one antiepileptic drug. Seizure. 2002; 11: 349-351.

3. Stephen LJ, Forsyth M, Kelly K, Brodie MJ. Antiepileptic drug combinations--have newer agents altered clinical outcomes? Epilepsy Res. 2012; 98: 194-198.

4. Brodie MJ, Barry SJ, Bamagous GA, Norrie JD, Kwan P. Patterns of treatment response in newly diagnosed epilepsy. Neurology. 2012; 78: 1548-1554.

5. Barker-Haliski M, Sills GJ, White HS. What are the arguments for and against rational therapy for epilepsy? Advances in experimental medicine and biology. 2014; 813: 295-308.

6. Perucca E. Pharmacological principles as a basis for polytherapy. Acta Neurol Scand Suppl. 1995; 162: 31-34.

7. Deckers CL, Czuczwar SJ, Hekster YA, Keyser A, Kubova H, Meinardi H, et al. Selection of antiepileptic drug polytherapy based on mechanisms of action: The evidence reviewed. Epilepsia, 2000; 41: 1364-1374.

8. Luszczki JJ, Czuczwar SJ. Preclinical profile of combinations of some second-generation antiepileptic drugs: An isobolographic analysis. Epilepsia. 2004; 45: 895-907.

9. Biton V, Gil-Nagel A, Isojarvi J, Doty P, Hebert D, Fountain NB. Safety and tolerability of lacosamide as adjunctive therapy for adults with partial-onset seizures: Analysis of data pooled from three randomized, double-blind, placebo-controlled clinical trials. Epilepsy Behav. 2015; 52: 119-127.

10. Luszczki JJ. Third-generation antiepileptic drugs: Mechanisms of action, pharmacokinetics and interactions. Pharmacol Rep. 2009; 61: 197-216. 
11. Zadeh WW, Escartin A, Byrnes W, Tennigkeit F, Borghs S, Li T, et al. Efficacy and safety of lacosamide as first add-on or later adjunctive treatment for uncontrolled partial-onset seizures: A multicentre open-label trial. Seizure. 2015; 31: 72-79.

12. Glauser T, Ben-Menachem E, Bourgeois B, Cnaan A, Guerreiro C, Kalviainen R, et al. Updated ILAE evidence review of antiepileptic drug efficacy and effectiveness as initial monotherapy for epileptic seizures and syndromes. Epilepsia. 2013; 54: 551-563.

13. Loscher W. Single versus combinatorial therapies in status epilepticus: Novel data from preclinical models. Epilepsy Behav. 2015; 49: 20-25.

14. Loscher W, Fassbender CP, Nolting B. The role of technical, biological and pharmacological factors in the laboratory evaluation of anticonvulsant drugs. II. Maximal electroshock seizure models. Epilepsy Res. 1991; 8: 79-94.

15. Tallarida RJ. Revisiting the isobole and related quantitative methods for assessing drug synergism. J Pharmacol Exp Ther. 2012; 342: 2-8.

16. Litchfield JT, Jr., Wilcoxon F. A simplified method of evaluating dose-effect experiments. J Pharmacol Exp Ther. 1949; 96: 99-113.

17. Loewe S. The problem of synergism and antagonism of combined drugs. Arzneimittelforschung. 1953; 3: 285-290.

18. Bourgeois BF, Wad N. Combined administration of carbamazepineand phenobarbital: effect on anticonvulsant activity and neurotoxicity. Epilepsia. 1988; 29: 482-487.

19. Shandra A, Shandra P, Kaschenko O, Matagne A, Stohr T. Synergism of lacosamide with established antiepileptic drugs in the 6-Hz seizure model in mice. Epilepsia. 2013; 54: 1167-1175.

20. Backus KH, Pflimlin P, Trube G. Action of diazepam on the voltage-dependent Na+ current. Comparison with the effects of phenytoin, carbamazepine, lidocaine and flumazenil. Brain Res. 1991; 548: 41-49.

21. Mathers DA, Wan X, Puil E. Barbiturate activation and modulation of GABA(A) receptors in neocortex. Neuropharmacology. 2007; 52: 1160-1168.

22. Twyman RE, Rogers CJ, Macdonald RL. Differential regulation of gamma-aminobutyric acid receptor channels by diazepam and phenobarbital. Ann Neurol. 1989; 25: 213-220.

23. Ko GY, Brown-Croyts LM, Teyler TJ. The effects of anticonvulsant drugs on NMDA-EPSP, AMPA-EPSP, and GABA-IPSP in the rat hippocampus. Brain Res Bull. 1997; 42: 297-302.

24. Errington AC, Stohr T, Heers C, Lees G. The investigational anticonvulsant lacosamide selectively enhances slow inactivation of voltage-gated sodium channels. Mol Pharmacol. 2008; 73: 157-169.

25. Stohr T, Kupferberg HJ, Stables JP, Choi D, Harris RH, Kohn H, et al. Lacosamide, a novel anti-convulsant drug, shows efficacy with a wide safety margin in rodent models for epilepsy. Epilepsy Res. 2007; 74: 147-154. 